\title{
Hydrological responses to climate change conditioned by historic alterations of land-use and water-use
}

\author{
J. Jarsjö, S. M. Asokan, C. Prieto, A. Bring, and G. Destouni \\ Department of Physical Geography and Quaternary Geology, Bert Bolin Centre for Climate Research, Stockholm University, \\ 10691 Stockholm, Sweden \\ Correspondence to: J. Jarsjö (jerker.jarsjo@natgeo.su.se)
}

Received: 21 July 2011 - Published in Hydrol. Earth Syst. Sci. Discuss.: 5 August 2011

Revised: 26 March 2012 - Accepted: 22 April 2012 - Published: 9 May 2012

\begin{abstract}
This paper quantifies and conditions expected hydrological responses in the Aral Sea Drainage Basin (ASDB; occupying $1.3 \%$ of the earth's land surface), Central Asia, to multi-model projections of climate change in the region from 20 general circulation models (GCMs). The aim is to investigate how uncertainties of future climate change interact with the effects of historic human re-distributions of water for land irrigation to influence future water fluxes and water resources. So far, historic irrigation changes have greatly amplified water losses by evapotranspiration (ET) in the ASDB, whereas 20th century climate change has not much affected the regional net water loss to the atmosphere. Results show that errors in temperature $(T)$ and precipitation $(P)$ from single GCMs have large influence on projected change trends (for the period 2010-2039) of river runoff $(R)$, even though the ASDB is spatially well resolved by current GCMs. By contrast, observed biases in GCM ensemble mean results have relatively small influence on projected $R$ change trends. Ensemble mean results show that projected future climate change will considerably increase the net water loss to the atmosphere. Furthermore, the ET response strength to any future $T$ change will be further increased by maintained (or increased) irrigation practices, which shows how climate change and water use change can interact in modifying ET (and $R$ ). With maintained irrigation practices, $R$ is likely to decrease to near-total depletion, with risk for cascading ecological regime shifts in aquatic ecosystems downstream of irrigated land areas. Without irrigation, the agricultural areas of the principal Syr Darya river basin could sustain a $50 \%$
\end{abstract}

higher $T$ increase (of $2.3^{\circ} \mathrm{C}$ instead of the projected $1.5^{\circ} \mathrm{C}$ until 2010-2039) before yielding the same consumptive ET increase and associated $R$ decrease as with the present irrigation practices.

\section{Introduction}

Human changes in land-use and water-use of the past century have considerably impacted the cycling of water and water-borne substances (Foley et al., 2005; Shibuo et al., 2006; Piao et al., 2007; Weiskel et al., 2007; Wisser et al., 2010). In particular, re-distribution of freshwater for irrigation of extensive agricultural areas (Shibuo et al., 2007; Lobell et al., 2009; Asokan et al., 2010; Destouni et al., 2010; Lee et al., 2011; Törnqvist and Jarsjö, 2012) has increased net water fluxes from the land surface to the atmosphere by about $2000 \mathrm{~km}^{3}$ per year, which constitutes the major part of the total human freshwater withdrawals (Foley et al., 2005; Gordon et al., 2005). Except for deforestation (Gordon et al., 2005), no other human modification has so far affected water fluxes to such an extent. These freshwater changes are significant and influence socio-economic development in most parts of the world. For instance, close to one billion people live in regions where agricultural yields have been much enhanced by irrigation (Keiser et al., 2005; Lobell and Field, 2007). Whereas agricultural efficiency needs to increase in order to decrease malnutrition and support a growing population, current high-yield agriculture is dependent on irrigation, 
fertilization, and pest control, which is associated with degradation of environmental resources from salinization, contamination, and water logging (Gordon et al., 2008; Johansson et al., 2009; Törnqvist et al., 2011).

In order to realistically plan for land-use and water-use changes, and efficiently mitigate the adverse effects of such changes, processes need to be understood and quantified on the drainage basin scale. This is best done within hydrological basins, because the topographical water divides that define these basins are physical boundaries that reasonably well delimit the flows of water and water-borne substances through the landscape, and the environmental impacts of man-made changes to these flows. Existence of large aquifer systems means that groundwater flows may extend over larger hydrological units than surface water basins. However, these subsurface flow effects decrease with increasing basin scale and can in many cases be investigated and quantified by state-of-the-art hydrogeological methods. The increasing hydrological impacts of climate change (Milly et al., 2005; Groves et al., 2008; Bengtsson, 2010) constitute a greater quantification challenge, with several open scientific questions in need of further investigation, not least regarding the large spatial scale discrepancy between a typical drainage basin and its hydrological modeling, and the global scale and coarse resolution of general circulation models (GCMs) (Milly et al., 2005; Groves et al., 2008).

Regionally, the impacts on water resources from changes in global atmospheric circulation and climate overlap with the impacts from land-use and water-use changes (Lobell and Field, 2007). For instance, in arid and semi-arid regions, water availability critically limits water-demanding agricultural expansion and economic growth, making such regions particularly vulnerable to impacts of expected future climate changes (IPCC, 2007). The different overlapping causes of freshwater resource changes make it hard to distinguish between various hydrological cause-effect relations and impacts (Milly et al., 2002; Piao et al., 2007; Destouni et al., 2008). However, for all water resource changes that are driven by different types of change at the surface of a hydrological basin, hydro-climatic change projections can be considerably improved by honoring and accounting for the water flux bounds implied by the basic basin-scale water balance equation $\mathrm{ET}=P-R-\Delta S$. Such bounds on the commonly difficult to measure and quantify vapour flux by evapotranspiration (ET) at the land surface can then be derived on basin scales from directly measured and/or modelinterpreted data on precipitation $(P)$ at the basin surface, runoff $(R)$ at the basin outlet, and storage change $(\Delta S)$ within the basin (Shibuo et al., 2007; Asokan et al., 2010; Destouni et al., 2010; Törnqvist and Jarsjö, 2012). Without such conditioning to water balance components, the Penman-Monteith type of evapotranspiration (ET) models can yield errors of $30 \%$ to $50 \%$ (Kite and Droogers, 2000), which is considerably larger than the errors of $10 \%$ to $15 \%$ that are involved in ET estimation from water balance closure (Asokan et al., 2010).

In this paper, we use and extend (from previous related studies of historic hydro-climatic change; Shibuo et al., 2007; Alekseeva et al., 2009; Destouni et al., 2010; Törnqvist and Jarsjö, 2012) such a basin-scale water balance approach to investigate future hydrological responses to projected climate change at the land surface of a hydrological basin. This is done by linking the projections of basin-scale surface climate change from 20 different GCMs with already developed hydrological modeling (based on the above-cited historic hydro-climatic change studies and data) for the example case of the closed and intensely irrigated Aral Sea Drainage Basin (ASDB) in Central Asia. We specifically analyze surface boundary-driven, multi-decadal hydrological changes, following the historic 20th century development of approximately 8 million hectares of irrigated land in the ASDB. The ASDB is one of the world's largest hydrological basins and is spatially well resolved by current GCMs. Furthermore, the dramatic Aral Sea shrinkage over the last $60 \mathrm{yr}$ constitutes a great amplifier of different water change signals, which has been used in previous water balance-based studies of the ASDB to understand and resolve the historic impacts of different hydro-climatic change drivers in this basin. A main question investigated here is then to what extent, and how, future climate change can interact with the human re-distributions of water in modifying future water fluxes and impacting future water resource availability. Such interactions with local-regional water resource management are not well resolved in current GCMs, or in regional climate models (RCMs). To complement such large-scale modeling, the present basin-scale water balance approach can explicitly consider and account for how various hydrological flows, such as ET, are limited by actual basin-scale human water and resulting water availability. We also investigate and provide example quantifications of main uncertainties in such modeling of hydrological responses to multi-GCM projections of future basin-scale climate change.

\section{Study area and historic hydro-climatic change}

With its total area of $1870000 \mathrm{~km}^{2}$, the ASDB occupies $1.3 \%$ of the Earth's land surface, and by its traditional definition, almost the entire region of Central Asia (Fig. 1). Records of hydrological responses to the historic changes in surface boundary conditions show that, despite a $P$ increase from the beginning of the 20th century (Fig. 1), the discharge $(Q)$ into the Aral Sea, through the principal rivers of Amu Darya and Syr Darya in the ASDB, has decreased from the pre-1950 value of about $60 \mathrm{~km}^{3} \mathrm{yr}^{-1}$ to today's average of less than $10 \mathrm{~km}^{3} \mathrm{yr}^{-1}$ (Fig. 1; Mamatov, 2003; Jarsjö and Destouni, 2004; Shibuo et al., 2007; Destouni et al., 2010). Such a $Q$ decrease may in principle be associated with a corresponding increase in the water vapor flux to the 

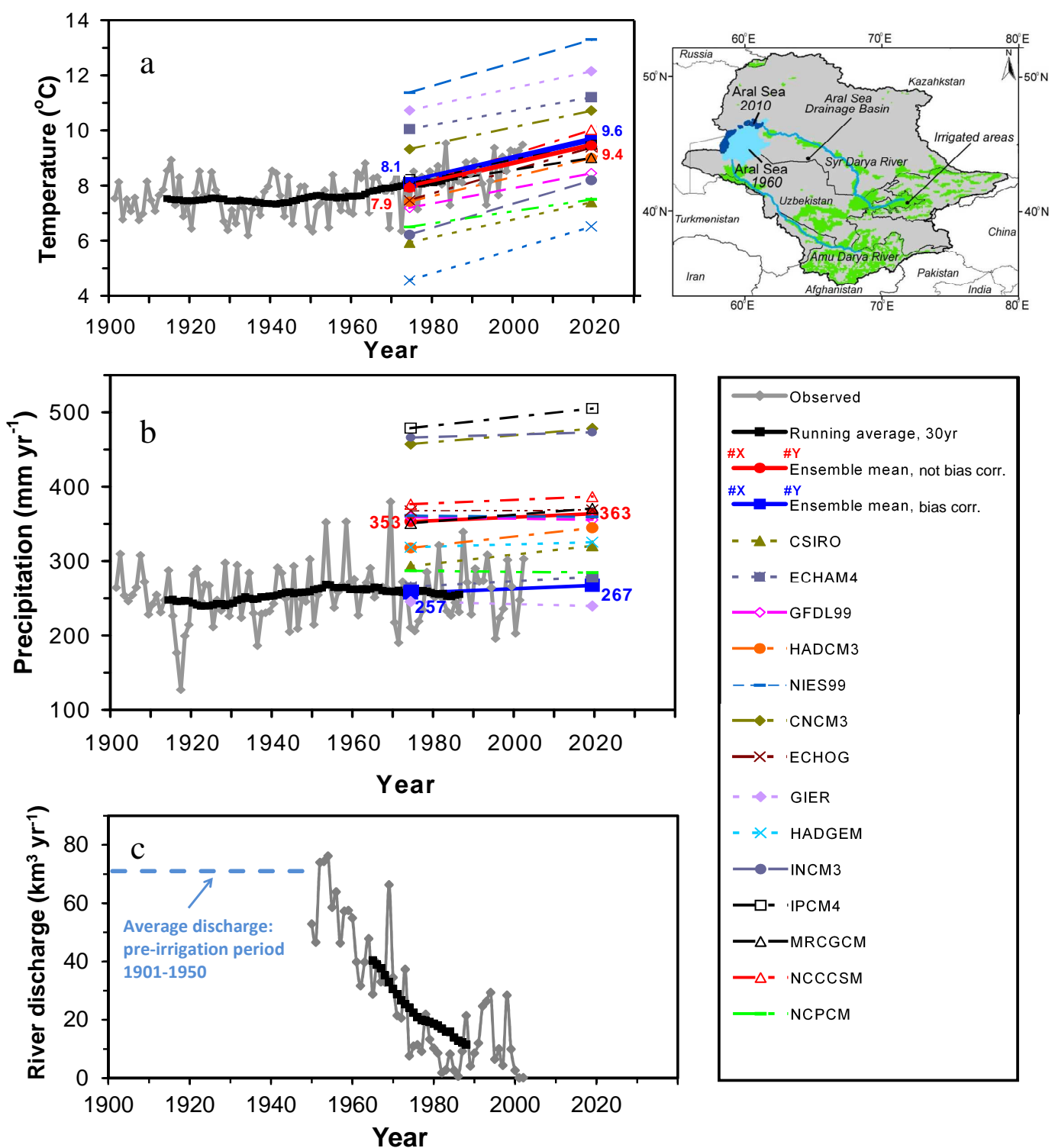

Fig. 1. Trends in (a) observed (grey line; running average in black) and projected (14 AR4 GCMs; colored thin lines) temperature $T$, (b) observed and projected precipitation $P$, and (c) observed river discharge $R$ at outlets, for the ASDB. Thick red lines show ensemble mean values of the GCM projections, and thick, blue lines show ensemble mean changes $(\Delta T$ and $\Delta P)$ from the observed mean conditions of the reference period 1961-1990. Insert map shows the extent and location of the ASDB (grey area), its irrigated land (green areas), the Aral Sea in 1960 (light blue) and in 2010 (dark blue), and the principal Amu Darya and Syr Darya rivers (blue).

atmosphere through ET, or in the groundwater recharge and associated diffuse groundwater discharges (DD) to the Aral Sea, or some combination of both. The fate of the missing water associated with a decrease in river discharge $Q$ must be estimated independently in order to resolve how much of the so far observed $Q$ change reflects an ET change, and how much should be attributed to a DD change.

In the ASDB, all diffuse groundwater flow converges into the terminal Aral Sea, contributing to its water level, which has decreased by $25 \mathrm{~m}$ since the 1960's. Detailed previous water balance studies with a coupled groundwater-seawater model and independent analyses of groundwater hydraulics have shown that this decrease is incompatible with large increases in DD (Jarsjö and Destouni, 2004; Shibuo et al., 2006; Alekseeva et al., 2009). Since the historic changes in DD are much smaller than the observed historic $Q$ changes in the ASDB, the latter must be due to ET changes of corresponding magnitude. Previously reported ASDB results have further shown that the ET losses associated with the historic, post-1950 temperature $(T)$ increase of $1{ }^{\circ} \mathrm{C}$ (Fig. 1a) are smaller than the historic water gains from increased $P$ (Fig. 1b), and that the drying of ASDB rivers ( $Q$ decrease; 
Fig. 1c) and associated major Aral Sea shrinkage have not so far been driven by the observed historic surface climate change within the ASDB (Shibuo et al., 2007).

\section{Future hydro-climatic change projections}

We consider future climate change scenarios for the ASDB (Fig. 1) by using the spatially distributed outputs for this basin from 20 General Circulation Models (GCMs). These comprise all available GCMs in the third and fourth assessment reports (TAR and AR4, respectively; Greenhouse Gas Emission Scenario A2a) of the Intergovernmental Panel of Climate Change (IPCC) (IPCC, 2007), from which both $T$ and $P$ output is available. As the ASDB extends over a considerable number of grid cells $(29 \pm 23)$ of the considered GCMs (Table 1), the GCM spatial resolution biases should be small (Wood et al., 2004; Milly et al., 2005; Mujumdar and Ghosh, 2008), justifying hydrological impact studies by direct use of GCM projection results for basins of this size. (Milly et al., 2002; Palmer and Räisänen, 2002).

\subsection{Catchment delineation and hydrological modeling steps}

The hydrological modeling considered here is spatially distributed, using the water module of the PCRaster-based Polflow model (De Wit, 2001), similar to previous investigations of historic hydro-climatic variability and change, specifically for the ASDB (Shibuo et al., 2007) as well as for other drainage basins in different parts of the world (Darracq et al., 2005; Jarsjö et al., 2008; Darracq and Destouni, 2009; Asokan et al., 2010). As input for the hydrological modeling module in PCRaster/PolFlow, each of the 9 million cells of the hydrological grid was assigned properties of ground slope and slope direction (based on the SRTM data), precipitation $P$ and temperature $T$ (30-yr average) from GCM output or observational data from the Climate Research Unit (CRU) TS 2.1 database (Mitchell and Jones, 2005), land use (classified as irrigated or not irrigated, from the Global Map of Irrigated Areas; Siebert et al., 2005), and land cover (classifying river water and reservoir grid cells, after Danko, 1992, and Johansson et al., 2009). The ground-slope and slope direction inputs were pre-processed using Shuttle Radar Topography Mission (SRTM) data (Farr et al., 2007), isobath data from Alekseeva et al. (2009), and stream location data from the Digital Chart of the World (Danko, 1992), associating each grid cell with a unique slope and flow direction $(\mathrm{N}, \mathrm{NE}, \mathrm{E}, \mathrm{S}, \mathrm{SW}, \mathrm{W}$, or $\mathrm{E}$, for a grid that is oriented in the $\mathrm{N}-\mathrm{S}$ and $\mathrm{E}-\mathrm{W}$ directions), into the neighbouring cell with the lowest elevation. Using PCRaster/PolFlow routines (De Wit, 2001), a topography-driven flow accumulation network of the ASDB was constructed by associating a sub-catchment area $\Omega_{i}$ to each grid cell $i$, including all upstream cells that contribute to the flow through the cell, on the basis of all
Table 1. Number of grid cells within the ASDB for the considered GCMs of IPCCs AR4 and TAR. The IDs of the GCMs are given as in the GCM summary by Solomon et al. (2007).

\begin{tabular}{lcc}
\hline ID of GCM & Version & $\begin{array}{c}\text { Number of grid } \\
\text { cells within ASDB }\end{array}$ \\
\hline CSIRO-CSMK3 & AR4 & 54 \\
ECHAM5-MPEH5 & AR4 & 56 \\
GFDL-GFCM_20_21 & AR4 & 37 \\
HADCM3 & AR4 & 20 \\
NIES-MIMR & AR4 & 24 \\
CNCM3 & AR4 & 24 \\
ECHOG & AR4 & 15 \\
GIER & AR4 & 11 \\
HADGEM & AR4 & 68 \\
INCM3 & AR4 & 7 \\
IPCM4 & AR4 & 19 \\
MRCGCM & AR4 & 23 \\
NCCCSM & AR4 & 99 \\
NCPCM & AR4 & 23 \\
CSIRO-MK2 & TAR & 11 \\
ECHAM4 & TAR & 26 \\
GFDL99-R30 & TAR & 24 \\
HADCM3 & TAR & 20 \\
CCSR/NIES & TAR & 6 \\
CCCMa-CGCM2 & TAR & 16 \\
\hline
\end{tabular}

upstream defined flow directions. Furthermore, for each cell, the locally created average precipitation surplus, PS, was calculated as $P$ - ET, in which the evapotranspiration (ET) was given according to Eqs. (1) to (7). Based on the calculated PS and the flow accumulation network, the total river discharge $(Q)$ and total runoff $(R)$ leaving a grid cell was finally obtained from the network-routed sum of PS.

In this way, the model can quantify the three principal outflow components of lake drainage basins, namely the discharges of the principal rivers into the lake (given in the model by $Q$ at the river outlet points at the Aral Sea), the diffuse flows along the shoreline of the lake (from groundwater and small, transient streams; given in the model by the sum of $R$ along the Aral Sea coastline), and ET over the land and water surfaces of the lake drainage basin (given in the model by the sum of actual ET over the basin's land surfaces and potential ET ( $\left(\mathrm{ET}_{\mathrm{p}}\right)$ over the basin's water surfaces). The annual mean ET (actual evapotranspiration) was estimated from the $\mathrm{ET}_{\mathrm{p}}$ (potential evapotranspiration) according to Turc (1954):

$\mathrm{ET}=\frac{P}{\sqrt{0.9+\frac{P^{2}}{\mathrm{ET}_{\mathrm{p}}^{2}}}}$

where ET, $\mathrm{ET}_{\mathrm{p}}$, and $P$ are expressed in $\mathrm{mm} \mathrm{yr}^{-1}$, and $\mathrm{ET}_{\mathrm{p}}$ was estimated as a function of $T$ according to Langbein (1949):

$\mathrm{ET}_{\mathrm{p}}=325+21 \cdot T+0.9 \cdot T^{2}$ 
where $T$ is expressed in ${ }^{\circ} \mathrm{C}$. In the present as in previously reported results from distributed hydrological modeling of the ASDB (Destouni et al., 2010; Shibuo et al., 2007) and elsewhere (Asokan et al., 2010), irrigation has been handled by spreading the known water diversions from rivers (currently $50 \mathrm{~km}^{3} \mathrm{yr}^{-1}$ from the ASDB rivers) over the known irrigated areas in the basin (from Siebert et al., 2005). More specifically, the superficial nature of the irrigation in the ASDB, which is dominated by furrow irrigation, was considered by adding the diverted water as extra $P$ over the irrigated fields, hence keeping them in a wetter state than prescribed by the $P$-data of CRU. This means that the water application of $50 \mathrm{~km}^{3} \mathrm{yr}^{-1}$ is an input to the model, whereas the associated water loss (i.e. consumptive water use) by contrast is an output, determined by the modeled amount of irrigation water (extra $P$ ) that remains in the basin after losses to the atmosphere through ET. The water diversions for agriculture considered here have constituted approximately $90 \%$ of the total water diversions of ASDB, since at least the 1960's. Moreover, in comparison with water diversions for other sectors such as the industrial and the municipal ones, the agricultural diversions can result in actual water consumption (i.e. physical loss of water from the surface of the basin) to a relatively large extent, due to the above-mentioned superficial nature of irrigation, which makes the diverted water relatively available for ET.

If the actual ET ( $\mathrm{ET}_{\mathrm{act}}$ ) of the ASDB for a given historical period were known from direct measurements, the performance of the adopted Langbein-Turc ET method (Eqs. 1 and 2) could be evaluated by determining a factor $X$ that quantifies how much the modeled, total ET over the basin $\left(\mathrm{ET}_{\mathrm{mod}}\right)$ differs from the actual ET $\left(\mathrm{ET}_{\mathrm{act}}\right)$ :

$\mathrm{ET}_{\mathrm{act}}=X \cdot \mathrm{ET}_{\mathrm{mod}}$

in which the factor $X$ equals unity for the case that the modeled $\mathrm{ET}$ independently reproduces $\mathrm{ET}_{\mathrm{act}}$. However, since $\mathrm{ET}_{\text {act }}$ cannot be obtained from direct measurements at basin scales, we estimate here $X$ from available observations of total precipitation over the drainage basin, $P_{\text {obs }}$ (Fig. 1b), and total river discharge $Q_{\mathrm{obs}}$ at the outlet of the drainage basin (Fig. 1c), according to the expression of Jarsjö et al. (2008):

$X=\frac{Q_{\mathrm{obs}}}{Q_{\mathrm{mod}}}+\left(1-\frac{Q_{\mathrm{obs}}}{Q_{\mathrm{mod}}}\right) \cdot \frac{P_{\mathrm{obs}}}{\mathrm{ET}_{\mathrm{mod}}}$

in which $Q_{\text {mod }}$ is the modeled total river discharge at the basin outlet, and all the variables to the right of the equal sign have units of volume per time. In Eq. (4), the value of $X$ represents a bias-factor by which the modeled total ET would need to be scaled, in order to obtain a calibrated model that reproduces the observed river discharge $Q_{\text {obs }}$. The factor $X$ equals unity if there is no bias, i.e. if the model independently can reproduce $Q_{\text {obs }}$ without any scaling of $\mathrm{ET}_{\text {mod }}$.

Considering also future hydro-climatic projections, the performance of the adopted Langbein-Turc ET method
(Eqs. 1 and 2) is compared with the Thorntwaite (1948) method that uses monthly climate data as input and therefore explicitly accounts for seasonal variations:

$\mathrm{ET}_{\mathrm{p}}=16 \cdot \frac{\mathrm{td}_{i}}{30} \cdot \frac{N_{i}}{12} \cdot\left(10 \cdot \frac{T_{i}}{I}\right)^{\alpha}$

in which $\operatorname{td}_{i}$ is the total number of days over which $\mathrm{ET}_{\mathrm{p}}$ is calculated, $N_{i}$ is the average day length in hours for month $i$, $T_{i}$ is the average temperature $\left({ }^{\circ} \mathrm{C}\right.$ ) for month $i$ (equals zero if the temperature is negative), and $I$ and $\alpha$ are given by:

$$
\begin{aligned}
& I=\sum_{i=1}^{12}\left(0.2 \cdot T_{i}\right)^{1.514} \\
& \alpha=6.75 \cdot 10^{-7} I^{3}-7.71 \cdot 10^{-5} \cdot I^{2}+1.79 \cdot 10^{-2} \cdot I+0.49 .
\end{aligned}
$$

The day lengths $N_{i}$ for ASDB were obtained from computations based on Meeus (1991), averaging the day lengths at latitude 40 and 45 .

\subsection{Quantification of multi-decadal hydro-climatic change}

The above-described hydrological model has previously been applied to both pre-irrigation conditions (without major water re-routings, i.e. before the 1950's), and current conditions (with present water diversions to irrigated fields) in the ASDB. Comparison with measurements (Fig. 1c) showed that the hydrological modeling could independently reproduce the observed long-term changes in river discharge without need of calibration or bias correction, implying that it is fully consistent with effects of historical, multi-decadal land-use and water-use driven changes in ASDB, the occurrence of which has so far greatly changed hydrological fluxes and water balances in the ASDB (Shibuo et al., 2007; Alekseeva et al., 2009, Destouni et al., 2010; Törnqvist and Jarsjö, 2012). More specifically, for the historical, pre-irrigation period in ASDB, Shibuo et al. (2007) used the same model as in this study, and reports $P_{\mathrm{obs}}=467 \mathrm{~km}^{3} \mathrm{yr}^{-1}, Q_{\mathrm{obs}}=71 \mathrm{~km}^{3} \mathrm{yr}^{-1}$, $Q_{\text {mod }}=77 \mathrm{~km}^{3} \mathrm{yr}^{-1}$, and $\mathrm{ET}_{\text {mod }}=391 \mathrm{~km}^{3} \mathrm{yr}^{-1}$, which yields a bias factor $X$ of 1.02 (Eq. 4) for the modeled ET implying that it would need to be just $2 \%$ higher to exactly obtain $Q_{\text {mod }}=Q_{\text {obs }}$ (Fig. 1c). The model hence yields consistent results under relatively undisturbed conditions. For their considered period 1983-2002, during which $50 \mathrm{~km}^{3} \mathrm{yr}^{-1}$ were re-routed to irrigated fields, Shibuo et al. (2007) reports $P_{\mathrm{obs}}=487 \mathrm{~km}^{3} \mathrm{yr}^{-1}, Q_{\mathrm{obs}}=12 \mathrm{~km}^{3} \mathrm{yr}^{-1}$, $Q_{\text {mod }}=16 \mathrm{~km}^{3} \mathrm{yr}^{-1}$, and $\mathrm{ET}_{\text {mod }}=458 \mathrm{~km}^{3} \mathrm{yr}^{-1}$, which yields a bias factor similarly close to unity $(X=1.02)$, as for the pre-irrigation period. This shows that the model results are also consistent with the observed effects (Fig. 1c) of the additional ET losses caused by the water re-routings to irrigated fields, and provides support for the model's predictive capacity of surface boundary-driven, multi-decadal hydrological changes at focus in this study. 
Shibuo et al. (2007) also investigated to what extent model performance in reproducing observed multi-decadal changes of ASDB could be further enhanced by use of monthly hydro-climatic data as input to ET quantifications by the Thornthwaite (1948) method. They found the latter to be similar and equally consistent with independent observations as the here-adopted Langbein (1949) ET method. Similar observation-consistent ET model results were also obtained between the Thornthwaite and Langbein methods under quite different multi-decadal water and climate change conditions in the Mahanadi River Basin of western India (Asokan et al., 2010), with the ET and $R$ results of the two models differing by at most $3 \%$. In addition to these different ET model comparisons, we report in the results section a comparison between the Langbein and Thortwaite ET method results, given example conditions of the here studied future climate projections.

For hydrological model results that account for irrigation, the irrigation and associated engineered water diversions are assumed to maintain their current states also in the near future (2010-2039). This makes it possible to evaluate the hydrological responses to projected climate changes in a basin that is already under considerable pressure from irrigation. Despite plans for possible continued irrigation expansion in the upper parts of ASDB (Rakhmatullaev et al., 2010), the present stable irrigation assumption is consistent with the acute regional water scarcity in Central Asia effectively prohibiting any actual further irrigation expansion in the lower basin parts (Törnqvist and Jarsjö, 2012). We further evaluate possible climate-irrigation interaction effects by calculating and comparing the different hydrological responses to projected climate change under an irrigation scenario (extending present irrigation conditions to the future) and a nonirrigation scenario (taking possible future irrigation halting to the limit of zero irrigation), as detailed below.

Furthermore, although hydrological modeling results were found to be consistent with historical records (Fig. 1c) without calibration need, the effects of biased $T$ and $P$ output from GCMs (Fig. 1a and b) on the modeling of future hydrological fluxes, such as runoff, are uncertain. Therefore, two alternative approaches are used to calculate future responses to climate change projections. Specifically, hydrological simulation results for the reference period 1961-1990 are based on (i) direct $T$ and $P$ output from GCM simulations, and (ii) CRU observational data on $T$ and $P$. Results for the future period 2010-2039 are then based on adding the absolute $\Delta T$ and $\Delta P$ values of the GCM change projections to (I) the GCM output for the reference period 1961-1990, and (II) the CRU observational data for 1961-1990. We call the latter case (ii) and (II) results bias-corrected, since they are fitted to, and hence agree with observational data for 19611990, whereas case (i) and (I) results are not bias-corrected, since they are based on direct GCM output (Fig. 1). For each of these GCM projection approaches I and II, the future climate-driven ET change $(\Delta \mathrm{ET})$ response is quantified as the difference in ET between the projected climate of the period 2010-2039 and the climate of the reference period 1961-1990. The effect of future irrigation development on $\triangle \mathrm{ET}$ is further investigated by considering two different irrigation scenarios: one scenario with irrigation maintained at present level in the basin (corresponding to a water application of $50 \mathrm{~km}^{3} \mathrm{yr}^{-1}$; yielding $\Delta \mathrm{ET}_{\text {irr }}$ ), and one without any future irrigation (corresponding to zero water application; yielding $\Delta \mathrm{ET}_{\mathrm{no} \text {-irr }}$ ).

In summary, hydrological simulations were performed for each of the considered GCMs (20 different), time periods (2 different), and irrigation scenarios (2 different), also duplicating the number of model runs by investigation of the two alternative approaches to hydro-climatic model coupling (i.e. bias-corrected and not bias-corrected). This hence resulted in a total of $20 \cdot 2 \cdot 2 \cdot 2=160$ hydro-climatic simulations. In addition, seeing from the simulation results for the two irrigation scenarios that the same projected $T$ increase yields climate-driven future $\Delta \mathrm{ET}_{\mathrm{no}-\mathrm{irr}}<\Delta \mathrm{ET}_{\mathrm{irr}}$, the $T$ increase needed to obtain $\Delta \mathrm{ET}_{\text {no-irr }}=\Delta \mathrm{ET}_{\text {irr }}$ is finally also estimated by adding small, uniform increases to the initial $T$ distribution of the entire ASDB in the model scenario without irrigation, until a match of $\Delta \mathrm{ET}_{\text {irr }}$ is obtained with the $\Delta \mathrm{ET}_{\text {no-irr }}$ scenario.

\section{Results}

Observation data for $T$ from the Climate Research Unit (CRU) TS 2.1 (grey line in Fig. 1a) show an average $T$ value of $8.1{ }^{\circ} \mathrm{C}$ within the ASDB (shaded in the upper right, overview panel of Fig. 1) for the reference period 19611990. The $T$ output of the 14 GCMs used in AR4 (colored, thin lines of Fig. 1a; the IDs of the different GCMs are given as in Solomon et al., 2007) show relatively large individual discrepancies from this observation, with for instance the average $T$ for the reference period ranging between 4.6 and $11.4^{\circ} \mathrm{C}$. The AR4 ensemble mean value (of $7.9^{\circ} \mathrm{C}$ ), however, is close to the observed average $T$. The projected $T$ increase $(\Delta T)$ for ASDB is also relatively consistent between the different GCMs, yielding an average future $T$ for the period 2010-2039 that is $1.5^{\circ} \mathrm{C}$ higher than $T$ for the reference period 1961-1990 (Fig. 1).

The AR4 model ensemble average $P$ value of $353 \mathrm{~mm} \mathrm{yr}^{-1}$ is considerably higher than the average $P$ of $257 \mathrm{~mm} \mathrm{yr}^{-1}$, based on $P$ observation data from CRU, for the reference period 1961-1990 (Fig. 1b). This is also the case for the TAR model ensemble average $P$ value of $334 \mathrm{~mm} \mathrm{yr}^{-1}$ (Table 2). Furthermore, the two AR4 GCMs that give $P$-values closest to observed $P$ (ECHAM4 and GIER) give $T$-values that are considerably above the observed $T$ (Fig. 1a), reflecting the fact that there is no single GCM that reasonably well reproduces both $P$ and $T$ for this large regional basin. Furthermore, the individual AR4 GCMs show quite different projected trends of $P$ 
Table 2. Summary of climate data from observations, ensemble mean results from the 14 AR4 and 6 TAR GCMs, and corresponding hydrological simulation results for the ASDB. Standard deviations are given in parentheses. Hydrological simulation results from all individual GCMs are given in the online supplementary material of this article.

\begin{tabular}{|c|c|c|c|c|}
\hline AR4 & $\begin{array}{r}\text { Observed } \\
1961-1990\end{array}$ & $\begin{array}{c}\text { GCM mean* } \\
\text { 1961-1990, } \\
\text { Not bias corr. }\end{array}$ & $\begin{array}{r}\text { GCM mean* } \\
2010-2039, \\
\text { Bias corr }\end{array}$ & $\begin{array}{r}\text { GCM mean* } \\
\text { 2010-2039, } \\
\text { Not bias corr. }\end{array}$ \\
\hline Average $T\left({ }^{\circ} \mathrm{C}\right)$ & 8.1 & $7.9(1.9)$ & $9.6(0.4)$ & $9.4(1.9)$ \\
\hline \multirow[t]{2}{*}{ Total $P\left(\mathrm{~km}^{3} \mathrm{yr}^{-1}\right)^{\mathrm{b}}$} & 481.7 & $670.7(140)$ & $501.1(23.7)$ & $690.1(149)$ \\
\hline & \multicolumn{4}{|c|}{ Mean* from hydrological model } \\
\hline Export $^{\mathrm{a}}$ & 13.4 & 13.4 & 13.4 & 13.4 \\
\hline Total ET $\left(\mathrm{km}^{3} \mathrm{yr}^{-1}\right)^{\mathrm{b}}$ & 458.2 & $522.3(76.7)$ & $482.3(16.2)$ & $550.1(84.9)$ \\
\hline Total $R\left(\mathrm{~km}^{3} \mathrm{yr}^{-1}\right)^{\mathrm{b}}$ & 10.1 & $135.0(94.5)$ & $5.5(9.3)$ & $126.7(99.8)$ \\
\hline TAR & $\begin{array}{r}\text { Observed } \\
1961-1990\end{array}$ & $\begin{array}{r}\text { GCM mean* } \\
\text { 1961-1990, } \\
\text { Not bias corr. }\end{array}$ & $\begin{array}{r}\text { GCM mean* } \\
2010-2039 \\
\text { Bias corr }\end{array}$ & $\begin{array}{r}\text { GCM mean* } \\
\text { 2010-2039, } \\
\text { Not bias corr. }\end{array}$ \\
\hline Average $T\left({ }^{\circ} \mathrm{C}\right)$ & 8.1 & $7.4(3.3)$ & $10.1(0.4)$ & $9.4(3.1)$ \\
\hline \multirow[t]{2}{*}{ Total $P\left(\mathrm{~km}^{3} \mathrm{yr}^{-1}\right)^{\mathrm{b}}$} & 481.7 & $633.7(176)$ & $503.6(47)$ & $655.7(145)$ \\
\hline & \multicolumn{4}{|c|}{ Mean* from hydrological model } \\
\hline Export $^{1}$ & 13.4 & 13.4 & 13.4 & 13.4 \\
\hline Total ET $\left(\mathrm{km}^{3} \mathrm{yr}^{-1}\right)^{\mathrm{b}}$ & 458.2 & $510.7(120)$ & $486.5(33.3)$ & $549.0(114)$ \\
\hline Total $R\left(\mathrm{~km}^{3} \mathrm{yr}^{-1}\right)^{\mathrm{b}}$ & 10.1 & $109.6(86.7)$ & $3.8(15.6)$ & $94.0(62.8)$ \\
\hline
\end{tabular}

change (decreasing, unchanged, or increasing), with the resulting model ensemble average value of future $P$ showing a slight increase of $10 \mathrm{~mm} \mathrm{yr}^{-1}$. The hydrological effects of differing future $P$ projections are then investigated here by adding the ensemble average $P$ change projection to: (I) the GCM ensemble average $P$ result for $1961-1990$, or (II) the actually observed average $P$ for 1961-1990.

Mean results of the two approaches (I) and (II) for the TAR and AR4 GCM projections show that, with maintained irrigation practices, ET from the ASDB can be expected to increase by around 25 to $40 \mathrm{~km}^{3} \mathrm{yr}^{-1}$ (Fig. 2). The difference between the ET results with and without bias-correction is much smaller for the AR4 $\left(3.8 \mathrm{~km}^{3} \mathrm{yr}^{-1}\right)$ than for the TAR $\left(10.2 \mathrm{~km}^{3} \mathrm{yr}^{-1}\right) \mathrm{GCM}$ results, indicating improved hydroclimatic change precision in the AR4 GCMs. The AR4 GCM projections (Fig. 2a) yield further a slightly smaller average ET change than the TAR GCM projections (Fig. 2b). The runoff $R$, which expresses the net annual basin-scale water availability after $P$ reduction by ET, is then expected to decrease by between 5 and $15 \mathrm{~km}^{3} \mathrm{yr}^{-1}$ due to the projected climate change between the periods 1961-1990 and 20102039 (Fig. 2). Such climate-driven near-future decreases in $R$ constitute a climate-effect trend break for the ASDB, as the climate-related $R$ change contribution experienced so far in this basin (with an average $1^{\circ} \mathrm{C} T$ increase trend for the

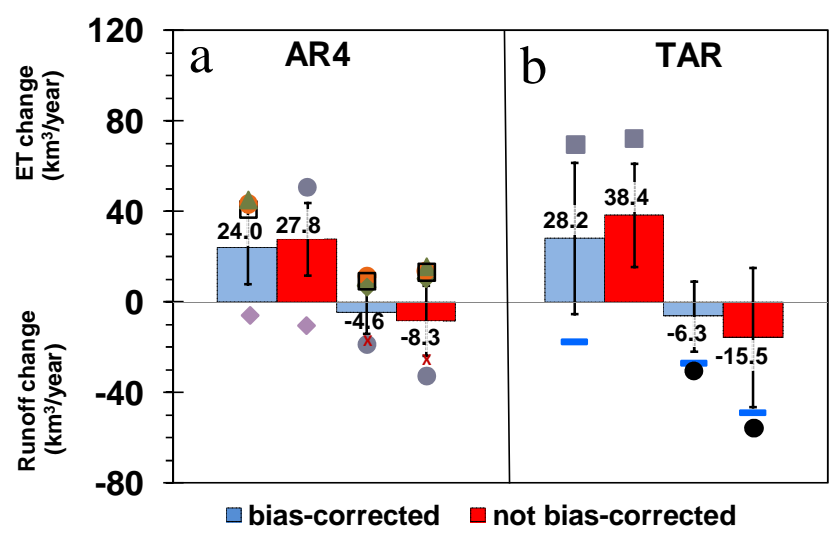

Fig. 2. Ensemble mean and standard deviation (error bars) of hydrological model results based on bias-corrected GCM projections (blue bars) and not bias-corrected GCM projections (red bars) of climate change from the reference period 1961-1990 to 2010-2039, based on (a) all 14 available GCM projections of AR4, and (b) all 6 available GCM projections of TAR. The symbols are consistent with those in Fig. 1 and show results outside of the standard deviation range. The black, filled circle that does not appear in Fig. 1 shows results based on the CCCma-CGCM2 model. 
last $50 \mathrm{yr}$ ) has not yet contributed much to the total historic $R$ decrease to present conditions (Shibuo et al., 2007). Also for $R$, the AR4 GCMs yield a smaller difference between $R$ results with and without bias-correction $\left(3.7 \mathrm{~km}^{3} \mathrm{yr}^{-1}\right)$ than the TAR GCMs $\left(9.2 \mathrm{~km}^{3} \mathrm{yr}^{-1}\right)$. The consistency between the results with and without bias-correction based on the GCM ensemble mean projections demonstrates that observed biases in GCM ensemble mean results have relatively small influence on projected $R$ change trends for this region (particularly for AR4 GCMs).

The error bars in Fig. 2 show the standard deviation of the modeled ET change and $R$ change results based on the 14 AR4 (Fig. 2a) and 6 TAR (Fig. 2b) GCMs. These standard deviations are larger than the difference in ensemble mean results between both the TAR and AR4 models, and the projection handling approaches with and without biascorrection. This implies that hydrological modeling coupled to single GCMs can deviate considerably from corresponding ensemble mean results, which is illustrated by the outlier GCM results in Fig. 2 (symbols), i.e. results that are outside of the standard deviation range. In particular, some individual GCM projections yield increasing $R$ (as can be understood from the outliers and the fact that the corresponding standard deviations in Fig. 2 include zero values), in contrast to all four combinations of ensemble mean results (AR4 bias-corrected, AR4 not bias-corrected, TAR bias-corrected and TAR not bias-corrected), which all yield decreasing $R$. Whereas the ensemble mean projections hence converge on yielding $R$ decrease results, the alternative approach of coupling hydrological modeling to a chosen single CGM can yield an opposing $R$ result, depending on the choice of GCM. This result also shows that the errors in $T$ and $P$ from single GCMs shown in Fig. 1 propagate critically to the main hydrologic output parameter $R$, which demonstrates that output uncertainties of single GCMs have large influence on projected $R$ change trends for this region.

Table 2 summarizes the observational and GCM ensemble mean data of the climate parameters of Fig. 1, and shows the corresponding absolute values of the hydrological model output that underpin the change results presented in Fig. 2 (corresponding standard deviations are shown in parenthesis). In addition, the hydrological model output from the individual hydrological model runs, with and without GCMbias correction, is given in the online supplementary material of this article, together with extended multi-model statistics for the TAR and AR4 ensembles (mean value, minimum value, maximum value, standard deviation, and $25 \%, 50 \%$, and $75 \%$ percentiles). In particular, Table 2 shows that there is a large difference in absolute $R$ between the bias-corrected and not bias-corrected approaches to GCM projection handling in the hydrological modeling. Without bias-correction, $R$ in the historic reference period (of $10 \mathrm{~km}^{3} \mathrm{yr}^{-1}$ ) is largely overestimated (by $135-10=125 \mathrm{~km}^{3} \mathrm{yr}^{-1}$ in the AR4 case; Table 2), mainly because the ensemble mean $P$ of the reference period is much overestimated by the GCMs (by $50 \%$; solid red line; Fig. 1b). It is unlikely that errors in the CRU dataset alone would be responsible for such large differences (with $P$-values of individual GCMs differing by up to $200 \%$ from the average $P$ of the CRU-dataset; Fig. 1b), since the data is averaged over the very large areas of the ASDB, and since the $P$ from the CRU-dataset has given consistent results when used as input in previous ASDB water balance modeling (e.g. Shibuo et al., 2007). Notably, even though the absolute $R$-value of the modeling without bias correction is more than 10 times too large, the associated result in terms of $R$-change is consistent with that from the bias-corrected modeling, as previously shown by the comparatively small difference between the red and blue bars in Fig. 2. The hydrological model results hence share this result characteristic with the GCM projections, in which $T$ and $P$ change $(\Delta T$ and $\Delta P$ ) can be robust even though corresponding absolute values ( $T$ and $P$ ) differ greatly between different GCMs and from observations.

For the considered periods 1961-1990 and 2010-2039 and the example climate output of the ECHOG GCM (brown lines in Fig. 1), the predicted total ET of the ASDB given by the adopted Langbein method differed by $4 \%$ and $3 \%$, respectively, from that of the alternative Thorntwaite method, which runs on a monthly resolution and therefore explicitly accounts for effects of seasonality. This is considerably smaller than the ET differences caused by the differing output of the considered GCMs (see e.g. the standard deviations presented in Table 2). We also tested the effect of refining the ET modeling by accounting for free-water evaporation from main rivers and reservoirs. This was done by using the expression for potential ET (ETp ; Eq. 2) at river water and reservoir grid cells, instead of the precipitation-limited expression for actual ET (Eq. 1). This resulted only in minor differences in predicted total ET from ASDB, on the order of $0.1-0.2 \%$. The characteristics of the presented ET change and runoff change results (Fig. 2) are hence relatively robust with regard to ET model choice. As mentioned in Sect. 3, this has also been seen in similar ET method comparisons of previous studies (Shibuo et al., 2007; Asokan et al., 2010).

For the ASDB, all multi-model projections converge on future climate change combined with maintained irrigation practices leading to expected $R$ decrease, which can entirely deplete the principal rivers in this basin within the next $40 \mathrm{yr}$ (Fig. 3, light blue bars). Analogous to Fig. 2, the relatively large standard deviation bars of Fig. 3 show that results based on individual GCMs can differ from the consistent multimodel trend of decreasing $R$. The symbols of Fig. 3 are the same as those of Fig. 1 and show the high end and low end results. Notably, the high end projection results show future $R$ values above the observed average in the later (1984-1989) years of the reference period 1961-1990, but below the average of the full reference period. Figure 3 also illustrates that the bias-correction of the GCM output has moved the high end and low end values of the hydrological projections 
(based on single GCMs) closer to the mean values of the multi-model ensembles.

The multi-model ensemble projections of (near-total) river depletion imply that relatively small changes in future $T$ and $P$ can lead to relatively large changes in $R$. This is a nonlinear $R$ response, considering that nearly equally large historic (20th century) $T$ and $P$ changes have so far yielded only small $R$ change contributions (Shibuo et al., 2007; Destouni et al., 2010). This non-linearity is also seen in the significantly lower $R$ in the later (1984-1989) years of the reference period 1961-1990 (Fig. 3, dark blue bars; runoff data from the Global Runoff Data Centre, Koblenz, Germany, available at http://grdc.bafg.de, and Mamatov, 2003), despite the fact that $T$ and $P$ were the same in these later years as over the full reference period. It is this non-linearity in the $R$ response that will yield total or near-total future river depletion, which is in turn associated with large risk for regime shifts in the aquatic ecosystems that depend on $R$ (Groves et al., 2008). This risk would not occur without the historic irrigation expansion that decreased the present $R$ so much (at least $50 \mathrm{~km}^{3} \mathrm{yr}^{-1}$ since the 1950 's) and left it, and the associated freshwater resources, highly vulnerable to any further ambient change. A main reason for this non-linear response is that ET approaches $P$ in magnitude. This means that relative changes in $R$ must become considerably larger than the corresponding relative changes in $P$ or ET, as can be understood from the basin-scale, long-term water balance $R=P-$ ET (i.e. since $R \rightarrow 0$ as ET $\rightarrow P$, it can change by orders of magnitude for relatively modest ET changes). For the historic period, the difference between $P$ and ET was larger, which made the system much less non-linear with regard to $R$ change.

Moreover, maintaining the historically developed irrigation practices stable also in the future will increase the hydrological ET sensitivity $(\Delta \mathrm{ET} / \Delta T)$ to future climate change $\Delta T$, and hence increase the regional strength of the ET response to increasing temperature. Specifically, the same $\Delta T$ will drive a considerably greater $\Delta \mathrm{ET}$ with irrigation $\left(\Delta \mathrm{ET}_{\text {irr }}\right)$ than without it $\left(\Delta \mathrm{ET}_{\text {no-irr }}\right)$, as shown in Fig. $4 \mathrm{a}$ by the resulting difference $\Delta \mathrm{ET}_{\text {irr }}-\Delta \mathrm{ET}_{\text {no-irr }}$ for the GCMprojected ensemble mean $\Delta T$ of $1.5^{\circ} \mathrm{C}$ for $2010-2039$.

Figure $4 \mathrm{~b}$ and $\mathrm{c}$ more generally illustrate the combined effects of $\Delta T$ and irrigation on $R$. Figure $4 \mathrm{~b}$ (left panel) illustrates the straight-forward ET response (red arrows) to increasing $\Delta T$ in non-irrigated areas, resulting in a decrease of $R$ that corresponds to the increase of ET due only to $\Delta T$. The blue arrows in Fig. 4 illustrate ET under current climate conditions (without $\Delta T$ ), which is higher in areas with irrigation (Fig. 4c, blue arrow) than without (Fig. $4 \mathrm{~b}-$ left, blue arrows). The red arrows in Figs. $4 \mathrm{~b}$ (left panel) and $4 \mathrm{c}$ show the ET response to the same $\Delta T=1.5^{\circ} \mathrm{C}$ in non-irrigated and in irrigated areas, respectively. Comparison between Fig. $4 \mathrm{~b}$ (right panel) and c finally illustrates that the agricultural areas along the Syr Darya river (the longest river in Central Asia) could without irrigation sustain a considerably

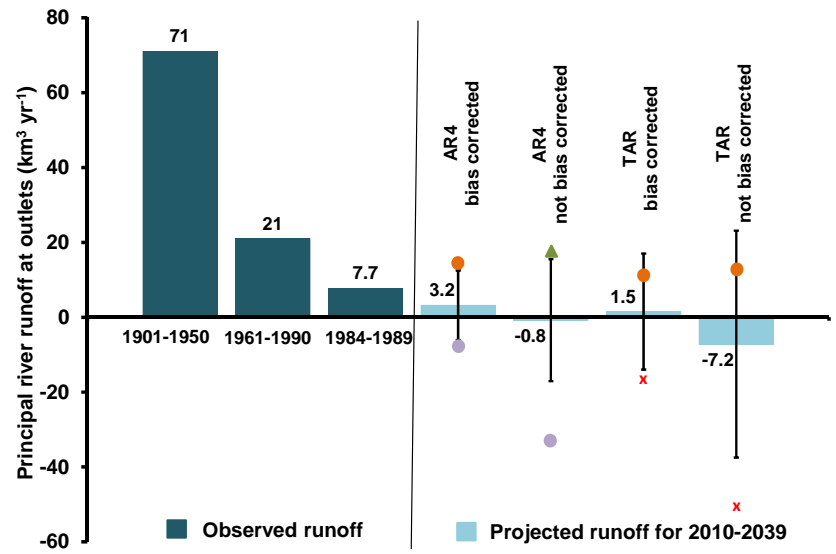

Fig. 3. Observed and projected total runoff of the principal Amu Darya and Syr Darya rivers at their Aral Sea outlets. The observed runoff changes so far are primarily due to irrigation expansion, whereas the future runoff results assume maintained irrigation practices following the 1984-1989 period, and quantify the effect of climate change from the reference period 1961-1990 to 2010-2039, for the same combinations of GCM projections and hydrological modeling methods as in Fig. 2. Light blue bars show ensemble mean values. Error bars show standard deviations. The symbols are consistent with those in Fig. 1 and show the extreme results. Negative numbers indicate water depletion upstream of the Aral Sea outlets.

higher temperature change, $\Delta T=2.3^{\circ} \mathrm{C}$ (Fig. $4 \mathrm{~b}-$ right), before yielding the same ET response as with the current irrigation practices and projected $\Delta T=1.5^{\circ} \mathrm{C}$ (Fig. 4c). This implies a $50 \%$ higher ET sensitivity to climate change with present irrigation practices than without any irrigation (i.e. $\left[\Delta \mathrm{ET}_{\text {irr }} / \Delta T_{\text {irr }}\right] /\left[\Delta \mathrm{ET}_{\text {no-irr }} / \Delta T_{\text {no-irr }}\right]=2.3{ }^{\circ} \mathrm{C} / 1.5^{\circ} \mathrm{C}=1.53$ for $\left.\Delta \mathrm{ET}_{\text {irr }}=\Delta \mathrm{ET}_{\text {no-irr }}\right)$. A direct consequence of increased ET sensitivity to $\Delta T$ is that the climate-driven future $R$ decrease is enhanced in irrigated areas, which may push downstream aquatic ecosystems closer to and beyond ecological regime shift thresholds.

\section{Discussion}

As found also in other studies (Rajagopalan et al., 2002; Kattsov et al., 2007; Nóbrega et al., 2011), model-related biases in hydro-climatic change projections can be considerably reduced by use of multi-model ensemble mean outputs of a larger set of GCMs (as in AR4), instead of output from just a few (as in TAR) or single GCMs. Therefore, and in contrast to most individual GCM results, multi-model ensemble results of AR4 GCMs have been found to reproduce historical discharges of some of the world's principal rivers. However, such ensemble projections have failed to reproduce historical river discharges when the rivers are heavily affected by human re-distributions of water (Nohara et al., 2006), as in the here considered ASDB. The present approaches to multiGCM projection handling, which use hydrological models 


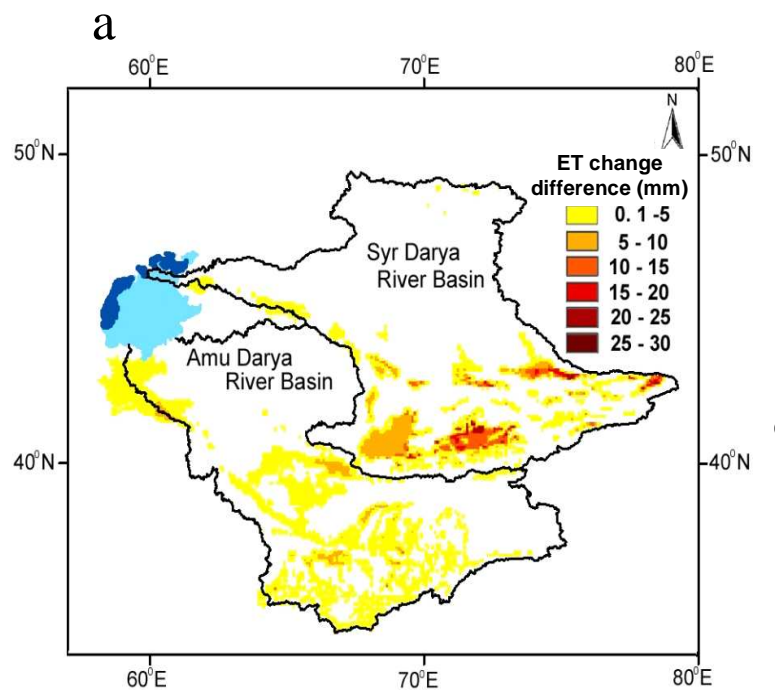

b scenarios without irrigation:

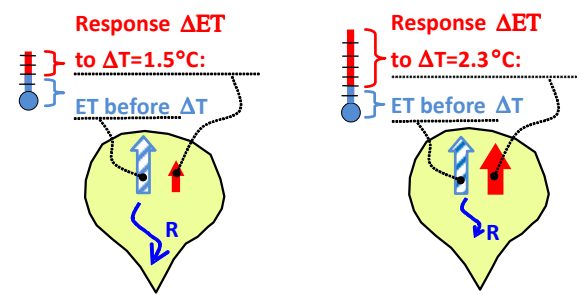

C Scenario with irrigation:

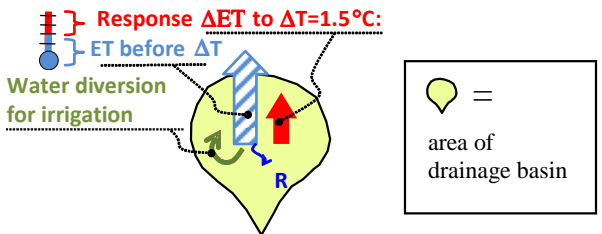

Fig. 4. (a) Difference between the irrigation and the non-irrigation scenario results for ET change from the reference period 1961-1990 to 2010-2039. The irrigation induced ET responses are schematically shown with red arrows in: (b) for the non-irrigation scenario and temperature increases of $1.5^{\circ} \mathrm{C}$ (left panel) and $2.3{ }^{\circ} \mathrm{C}$ (right panel), and (c) for the irrigation scenario and temperature increase of $1.5^{\circ} \mathrm{C}$.

that reproduce observed river discharges of the ASDB by accounting for its internal water re-distributions, converge on showing that expected future $T$ and $P$ changes in the ASDB will decrease $R$ in the near-future period 2010-2039 considerably more with than without continued irrigation practices. This is due to the irrigation increase of ET and associated net losses of water from the basin to the atmosphere. These increased water losses may or may not be temporarily masked by runoff increases from internal water storage changes within the basin (e.g. caused by glacier melt; Radić and Hock, 2011).

More generally, a similar comparison of not bias-corrected GCM results with observation data of $T$ and $P$, carried out by Bring and Destouni (2011) for major river basins in the hydro-climatically very different Arctic region, yielded consistent results with those obtained here for the Central Asian ASDB. That is, ensemble mean GCM results represent observation data much better for $T$ than for $P$, and largely overestimate $P$ and its recent historic change so far for the Arctic region, similarly to the present Central Asian region of the ASDB. Furthermore, also for the Arctic, inter-GCM variability is larger for the (fewer) TAR than for the (considerably more) AR4 GCMs, implying greater precision, even though not much better accuracy with regard to $P$, for AR4.

The off-line, basin-scale water balance approach adopted here to the modeling of hydrological change responses to climate change implies that considerably refined hydrological routines (relative to the commonly very coarse hydrological process and result resolution in GCMs) can be coupled to a large number of GCMs (20 in the present case). Adopting a corresponding on-line approach for all different GCMs - i.e. implementing in each of them physically based and well-resolved hydrological routines that feed the regional hydrological model output back into the GCM and re-running it for all considered scenarios - would be a huge task, also because the resolving of the continents' water balances on basin-scales would require much finer GCM grids than those used in the TAR and the AR4 of IPCC. The alternative of implementing a corresponding on-line approach to a single chosen GCM can, for instance, provide more generic insights into the dynamics of feedback mechanisms. However, the current ASDB example illustrates that conclusions regarding even the direction of $R$ change (increasing or decreasing), drawn from a single GCM can contradict converging conclusions drawn from several, quite different multimodel approaches using ensemble mean GCM projections. Hence, results on the hydro-climatic development in ASDB can remain inconclusive if based on a single GCM. Based on the similar recent implications also for the very different Arctic region hydrology (Bring and Destouni, 2011), this is a conclusion that may hold true more generally for many of the world's hydrological basins, most of which are also considerably smaller than the ASDB, which increases GCM resolution biases and uncertainties relative to the ASDB.

The here considered no-irrigation scenario is a hypothetical, limiting case of irrigation reduction, which shows how irrigation contributes to river flow depletion under different ambient conditions. The large water use reductions considered in this scenario have practical relevance, since there is potential for considerably reducing the water application on the irrigated fields of the ASDB. This is because its current irrigation practices are among the world's most inefficient. For instance, the amount of water applied per arable area is in many cases several times higher in the ASDB than in other comparable regions. As shown by Törnqvist and Jarsjö (2012), even relatively modest improvements in 
irrigation techniques could increase the discharge of ASDB's principal rivers by a couple of cubic kilometers per year. Furthermore, a given change of irrigation techniques could be up to four times more efficient if implemented in some regions of the ASDB than in others, mainly due to a relatively large influence of regional climate conditions on water losses. Overall, this demonstrates that the water application could be reduced even if the current, water demanding cotton and rice production is maintained. The water application could be reduced much more if alternative, less water demanding crops were introduced.

The here quantified increase in ET (and associated $R$ ) response sensitivity to $T$ change with irrigation, relative to without it, implies more generally that global expansion of irrigation can considerably increase the adversity of future climate change effects on the world's water resources. It can also change the spatial distribution of ET-related continental water feedbacks to climate change. Despite the large potential for reducing irrigation water losses in ASDB, continued irrigation expansion planned by Central Asian states (Rakhmatullaev et al., 2010) may cause even greater ET losses and extend downstream river depletion in comparison to the case of maintained irrigation practices considered here. The countries of the upstream, mountainous parts of ASDB also plan to increase the use of hydropower. Water would then increasingly be discharged during cold periods, which implies increased upstream water storage and decreased downstream water availability during the growing season. Water-efficient irrigation practices are needed to evade these more adverse effects of changes in climate, landuse and water use.

\section{Conclusion and summary}

- All multi-model projections converge on showing that future climate change combined with maintained irrigation practices will lead to $R$ decreases that can entirely deplete the principal rivers in ASDB within the next $40 \mathrm{yr}$.

- This total or near-total climate change-driven river depletion would not occur without the historic irrigation expansion that has so far decreased $R$ to its present low level.

- Without irrigation, the agricultural areas of the principal Syr Darya river basin could be subject to a $50 \%$ higher temperature increase before yielding the same consumptive ET increase, and associated $R$ decrease, as with continued irrigation practices at present level.

- Conclusions drawn from single GCM projections regarding even the direction of future $R$ changes (increasing or decreasing) in the ASDB are not robust, i.e. single GCM projections can entirely contradict converging conclusions from quite different approaches to handling multi-GCM ensemble mean projections in hydrological modeling.

\section{Supplementary material related to this article is available online at: http://www.hydrol-earth-syst-sci.net/ 16/1335/2012/hess-16-1335-2012-supplement.zip.}

Acknowledgements. This study was financially supported by the Swedish International Development Cooperation Agency (SIDA) and the Swedish Research Council (VR; project number 2006-4366, contract number 60436601).

Edited by: W. Buytaert

\section{References}

Alekseeva, I., Jarsjö, J., Schrum, C., and Destouni, G.: Reproducing the Aral Sea water budget and sea-groundwater dynamics between 1979 and 1993 using a coupled 3-D sea-ice-groundwater model, J. Mar. Syst., 76, 296-309, 2009.

Asokan, S. M., Jarsjö, J., and Destouni, G.: Vapor flux by evapotranspiration: Effects of changes in climate, land use, and water use, J. Geophys. Res.-Atmos., 115, D24102, doi:10.1029/2010JD014417, 2010.

Bengtsson, L.: The global atmospheric water cycle, Environ. Res Lett., 5, 025002, doi:10.1088/1748-9326/5/2/025002, 2010.

Bring, A. and Destouni, G.: Relevance of hydro-climatic change projection and monitoring for assessment of water cycle changes in the Arctic, AMBIO, 40, 361-369, 2011.

Danko, D. M.: The digital chart of the world project, Photogramm. Eng. Remote Sens., 58, 1125-1128, 1992.

Darracq, A. and Destouni, G.: Nutrient cycling and N2O emissions in a changing climate: The subsurface water system role, Environ. Res. Lett., 4, 035008, doi:10.1088/1748-9326/4/3/035008, 2009.

Darracq, A., Greffe, F., Hannerz, F., Destouni, G., and Cvetkovic, V.: Nutrient transport scenarios in a changing Stockholm and Mälaren valley region, Sweden, Water Sci. Technol., 51, 31-38, 2005.

De Wit, M. J. M.: Nutrient fluxes at the river basin scale, I: The Polflow model, Hydrol. Process., 15, 743-759, 2001.

Destouni, G., Hannerz, F., Prieto, C., Jarsjö, J., and Shibuo, Y.: Small unmonitored near-coastal catchment areas yielding large mass loading to the sea, Global Biogeochem. Cy., 22, GB4003, doi:10.1029/2008GB003287, 2008.

Destouni, G., Asokan, S. M., and Jarsjö, J.: Inland hydro-climatic interaction: Effects of human water use on regional climate, Geophys. Res. Lett., 37, L18402, doi:10.1029/2010GL044153, 2010.

Farr, T. G., Rosen, P. A., Caro, E., Crippen, R., Duren, R., Hensley, S., Kobrick, M., Paller, M., Rodriguez, E., Roth, L., Seal, D. Shaffer, S., Shimada, J., Umland, J., Werner, M., Oskin, M., Burbank, D., and Alsdorf, D. E.: The shuttle radar topography mission, Rev. Geophys., 45, RG2004, doi:10.1029/2005RG000183, 2007. 
Foley, J. A., DeFries, R., Asner, G. P., Barford, C., Bonan, G., Carpenter, S. R., Chapin, F. S., Coe, M. T., Daily, G. C., Gibbs, H. K., Helkowski, J. H., Holloway, T., Howard, E. A., Kucharik, C. J., Monfreda, C., Patz, J. A., Prentice, I. C., Ramankutty, N., and Snyder, P. K.: Global consequences of land use, Science, 309, 570-574, 2005.

Gordon, L. J., Steffen, W., Jönsson, B. F., Folke, C., Falkenmark, M., and Johannessen, Å.: Human modification of global water vapor flows from the land surface, P. Natl. Acad. Sci. USA, 102, 7612-7617, 2005.

Gordon, L. J., Peterson, G. D., and Bennett, E. M.: Agricultural modifications of hydrological flows create ecological surprises, Trends Ecol. Evol., 23, 211-219, 2008.

Groves, D. G., Yates, D., and Tebaldi, C.: Developing and applying uncertain global climate change projections for regional water management planning, Water Resour. Res., 44, W12413, doi:10.1029/2008WR006964, 2008.

IPCC: Climate change 2007: Synthesis report, Contribution of Working Groups I, II and III to the Fourth Assessment Report of the Intergovernmental Panel on Climate Change, 104, 2007.

Jarsjö, J. and Destouni, G.: Groundwater discharge into the Aral Sea after 1960, J. Mar. Syst., 47, 109-120, 2004.

Jarsjö, J., Shibuo, Y., and Destouni, G.: Spatial distribution of unmonitored inland water discharges to the sea, J.Hydrol., 348, 5972, 2008.

Johansson, O., Aimbetov, I., and Jarsjö, J.: Variation of groundwater salinity in the partially irrigated Amudarya River delta, Uzbekistan, J. Mar. Syst., 76, 287-295, 2009.

Kattsov, V. M., Walsh, J. E., Chapman, W. L., Govorkova, V. A., Pavlova, T. V., and Zhang, X.: Simulation and projection of Arctic freshwater budget components by the IPCC AR4 global climate models, J. Hydrometeorol., 8, 571-589, 2007.

Keiser, J., De Castro, M. C., Maltese, M. F., Bos, R., Tanner, M., Singer, B. H., and Utzinger, J.: Effect of irrigation and large dams on the burden of malaria on a global and regional scale, Am. J. Trop. Med. Hyg., 72, 392-406, 2005.

Kite, G. W. and Droogers, P.: Comparing evapotranspiration estimates from satellites, hydrological models and field data, J. Hydrol., 229, 3-18, 2000.

Langbein, W. B.: Annual runoff in the United States, US Geological Survey Circular, 52, US Dept. of the Interior, Washington, DC, USA, 14 pp., 1949.

Lee, E., Sacks, W. J., Chase, T. N., and Foley, J. A.: Simulated impacts of irrigation on the atmospheric circulation over Asia, J. Geophys. Res.-Atmos., 116, D08114, doi:10.1029/2010JD014740, 2011.

Lobell, D., Bala, G., Mirin, A., Phillips, T., Maxwell, R., and Rotman, D.: Regional differences in the influence of irrigation on climate, J. Climate, 22, 2248-2255, 2009.

Lobell, D. B. and Field, C. B.: Global scale climate-crop yield relationships and the impacts of recent warming, Environ. Res. Lett., 2, 014002, doi:10.1088/1748-9326/2/1/014002, 2007.

Mamatov, S.: Study of the groundwater contribution to the Aral Sea region water supply and water quality: Strategies for reversibility and pollution control - INTAS project 1014, EU-INTAS Aral Sea Basin Call 2000, Group CR5 Status Report, European Commission, Bruxelles, Belgium, 30 April 2003.

Meeus, J.: Astronomical algorithms, Willmann-Bell, Richmond, VA, ISBN 0943396352, 1st Edn., 429 pp., 1991.
Milly, P. C. D., Wetherald, R. T., Dunne, K. A., and Delworth, T. L.: Increasing risk of great floods in a changing climate, Nature, 415, 514-517, 2002.

Milly, P. C. D., Dunne, K. A., and Vecchia, A. V.: Global pattern of trends in streamflow and water availability in a changing climate, Nature, 438, 347-350, 2005.

Mitchell, T. D. and Jones, P. D.: An improved method of constructing a database of monthly climate observations and associated high-resolution grids, Int. J. Climatol., 25, 693-712, 2005.

Mujumdar, P. P. and Ghosh, S.: Modeling GCM and scenario uncertainty using a possibilistic approach: Application to the Mahanadi River, India, Water Resour. Res., 44, W06407, doi:10.1029/2007WR006137, 2008.

Nóbrega, M. T., Collischonn, W., Tucci, C. E. M., and Paz, A. R.: Uncertainty in climate change impacts on water resources in the Rio Grande Basin, Brazil, Hydrol. Earth Syst. Sci., 15, 585-595, doi:10.5194/hess-15-585-2011, 2011.

Nohara, D., Kitoh, A., Hosaka, M., and Oki, T.: Impact of climate change on river discharge projected by multimodel ensemble, J. Hydrometeorol., 7, 1076-1089, 2006.

Palmer, T. N. and Räisänen, J.: Quantifying the risk of extreme seasonal precipitation events in a changing climate, Nature, 415, 512-514, 2002.

Piao, S., Friedlingstein, P., Ciais, P., De Noblet-Ducoudré, N., Labat, D., and Zaehle, S.: Changes in climate and land use have a larger direct impact than rising $\mathrm{CO}_{2}$ on global river runoff trends, P. Natl. Acad. Sci. USA, 104, 15242-15247, 2007.

Radić, V. and Hock, R.: Regionally differentiated contribution of mountain glaciers and ice caps to future sea-level rise, Nat. Geosci., 4, 91-94, 2011.

Rajagopalan, B., Lall, U., and Zebiak, S. E.: Categorical climate forecasts through regularization and optimal combination of multiple GCM ensembles, Mon. Weather Rev., 130, 1792-1811, 2002.

Rakhmatullaev, S., Huneau, F., Kazbekov, J., Le Coustumer, P., Jumanov, J., El Oifi, B., Motelica-Heino, M., and Hrkal, Z.: Groundwater resources use and management in the Amu Darya River Basin (Central Asia), Environ. Earth Sci., 59, 1183-1193, 2010.

Shibuo, Y., Jarsjö, J., and Destouni, G.: Bathymetry-topography effects on saltwater-fresh groundwater interactions around the shrinking Aral Sea, Water Resour. Res., 42, W11410, doi:10.1029/2005WR004207, 2006.

Shibuo, Y., Jarsjö, J., and Destouni, G.: Hydrological responses to climate change and irrigation in the Aral Sea drainage basin, Geophys. Res. Lett., 34, L21406, doi:10.1029/2007GL031465, 2007.

Siebert, S., Döll, P., Hoogeveen, J., Faures, J.-M., Frenken, K., and Feick, S.: Development and validation of the global map of irrigation areas, Hydrol. Earth Syst. Sci., 9, 535-547, doi:10.5194/hess-9-535-2005, 2005.

Solomon, S., Qin, D., Manning, M., Chen, Z., Marquis, M., Averyt, K. B., Tignor, M., and Miller, H. L.: The Physical Science Basis, Contribution of Working Group I to the Fourth Assessment Report of the Intergovernmental Panel on Climate Change, Cambridge University Press, Cambridge, UK, 2007.

Thornthwaite, C. W.: An approach toward a rational classification of climate, Geogr. Rev., 38, 55-94, 1948. 
Törnqvist, R. and Jarsjö, J.: Water Savings Through Improved Irrigation Techniques: Basin-Scale Quantification in Semi-Arid Environments, Water Resour. Manage., 26, 949-962, 2012.

Törnqvist, R., Jarsjö, J., and Karimov, B.: Health risks from largescale water pollution: Trends in Central Asia, Environ. Int., 37, 435-442, 2011.

Turc, L.: Le bilan d'eau des sols: Relations entre les précipitations l'évaporation et l'écoulement, Ann. Agron., 5, 491-595, 1954.

Weiskel, P. K., Vogel, R. M., Steeves, P. A., Zarriello, P. J., DeSimone, L. A., and Ries III, K. G.: Water use regimes: Characterizing direct human interaction with hydrologic systems, Water Resour. Res., 43, W04402, doi:10.1029/2006WR005062, 2007.
Wisser, D., Fekete, B. M., Vörösmarty, C. J., and Schumann, A. H.: Reconstructing 20th century global hydrography: a contribution to the Global Terrestrial Network- Hydrology (GTN-H), Hydrol. Earth Syst. Sci., 14, 1-24, doi:10.5194/hess-14-1-2010, 2010.

Wood, A. W., Leung, L. R., Sridhar, V., and Lettenmaier, D. P.: Hydrologic implications of dynamical and statistical approaches to downscaling climate model outputs, Climatic Change, 62, 189216, 2004. 